\title{
Recurrent Hypoglycaemia in a Diabetic Patient Presented a Gastric Cancer: Think about Paraneoplastic Syndrome
}

\author{
Ruffin Randriamalala', Lovasoa Tika ${ }^{2}$, Mampionona Ranaivomanana ${ }^{3}$, \\ Andriamiarimbola Irène Rakotoniaina ${ }^{4}$, Florine Rafaramino², Andry Riel ${ }^{5}$ \\ ${ }^{1}$ Department of Cancerology and Polyvalent Medicine, University Hospital, Tuléar, Madagascar \\ ${ }^{2}$ Cancerology Department, University Hospital, Antananarivo, Madagascar \\ ${ }^{3}$ Cancerology Department, University Hospital, Fianarantsoa, Madagascar \\ ${ }^{4}$ Laboratory Department, University Hospital, Tuléar, Madagascar \\ ${ }^{5}$ Reanimation Department, University Hospital, Tuléar, Madagascar \\ Email: njarouffin@yahoo.fr
}

How to cite this paper: Randriamalala, R., Tika, L., Ranaivomanana, M., Rakotoniaina, A.I., Rafaramino, F. and Riel, A. (2019) Recurrent Hypoglycaemia in a Diabetic Patient Presented a Gastric Cancer: Think about Paraneoplastic Syndrome. Case Reports in Clinical Medicine, 8, 196-203. https://doi.org/10.4236/crcm.2019.87024

Received: April 26, 2019

Accepted: July 21, 2019

Published: July 24, 2019

Copyright $\odot 2019$ by author(s) and Scientific Research Publishing Inc. This work is licensed under the Creative Commons Attribution International License (CC BY 4.0).

http://creativecommons.org/licenses/by/4.0/

(c) (i) Open Access

\begin{abstract}
The hypoglycaemia paraneoplastic is uncommon in diabetic patients. Our aim was to report a case of paraneoplastic hypoglycaemia discovered after the diagnosis of gastric adenocarcinoma in a diabetic patient. A 65 years old man, was hospitalized for the management of acute digestive haemorrhage. In his medical history, he had diabetes since 20 years. He was alcoholic weaned for 3 years and had an unexplored repetitive epigastralgia. During his hospitalization, the exploration of acute digestive haemorrhage found a gastric adenocarcinoma with hepatic metastasis. At the $4^{\text {th }}$ day of his hospitalization, he presented a hypoglycaemic coma with capillary blood glucose at $0.36 \mathrm{~g} / \mathrm{L}$. The patient was conscious after the infusion of Hypertonic Glucose Solution (HGS) 10\%. After 3 days, the recurrent hypoglycaemia occurred and we intermittently treated by infusion of glucose solution $10 \%$. The measurements of insulin level and C-peptide weren't performed because they didn't exist in the city. So, the notion of cancer and the recurrent hypoglycaemia even if we stopped the oral antidiabetic therapy make us think of a paraneoplastic syndrome. The chemotherapy associated with corticosteroid therapy is the standard treatment of the hypoglycaemia paraneoplastic but the patient refused the chemotherapy and we couldn't use the corticosteroid therapy because of digestive haemorrhage. At the end of his hospitalization, he still had hypoglycaemia treated by infusion of glucose solution $10 \%$. In the absence of means of diagnosis, we should think of paraneoplastic syndrome in front of recurrent hypoglycaemia and cancer in the diabetic patient.
\end{abstract}




\section{Keywords}

Extrapancreatic Tumors, Gastric Carcinoma, Hypoglycaemia, Paraneoplastic Syndrome

\section{Introduction}

In the diabetic patient treated by insulin or hypoglycaemic sulfamide, the hypoglycaemia is one common acute complication but it is rare in the context of paraneoplastic syndrome. The cause of this syndrome is either an insulinoma or extrapancreatic cancers. In the $45 \%$ of cases, the extra-pancreatic cancer comes from the mesenchymal tissue in the $45 \%$ of cases and rarely, it comes from the epithelial tissue [1] [2] [3] [4]. The paraneoplastic hypoglycaemia is due to the secretion of a precursor of high molecular weight of "Insulin-like Growth Factor-2" (IGF-2) or "big IGF-2"; this precursor mimics the effects of insulin [5] [6] [7]. In the diabetic patients, the causes of hypoglycaemia must be sought to differentiate the reactive hypoglycaemia and the organic hypoglycaemia like the paraneoplastic hypoglycaemia [8]. Indeed, this one can be under diagnosed in case of tumoral pathologies. Sometimes, it is the premature sign of some cancers [9] [10] [11]. Our aim was to report a case of paraneoplastic hypoglycaemia discovered after the diagnosis of gastric adenocarcinoma in the diabetic patient. An informed consent was obtained from the patient to report this case.

\section{Case History}

A 65 years old man, state employee retired, was hospitalized at the department of oncology and polyvalent medicine of the University Center Hospital of Antanambao Toliara, in the south of Madagascar for the management of acute digestive haemorrhage.

In his medical history, he had diabetes since 20 years treated by oral antidiabetic (glibenclamide). His treatment was taken irregularly and was stopped since a few months after a discomfort. He was chronic alcoholic who has been weaned for 3 years. He had a repetition epigastralgia not exploring and a repetition discomfort since a few months. In his eating habits, he took cassava 2 times a day and rice once a day.

At the admission, he was conscious, his hemodynamic state was stable. His general state was deteriorated and he presented a cutaneo-mucosal pallor. The abdomen was flexible; there was an epigastric pain without portal hypertension signs. There were blackish stools at the digital rectal examination

He was fasted and his treatment was composed of red blood cell transfusion, plasma transfusion, parenteral alimentation and medicaments to eradicate Helicobacter pylori (amoxicillin, omeprazole, clarythromycin during 14 days).

After he underwent a digestive endoscopy and we found a bloody bulging mass at the fundus of stomach. We practiced a biopsy of mass and the histologi- 
cal examination found a gastric adenocarcinoma.

The evolution of digestive haemorrhage was favourable on the $2^{\text {nd }}$ day of his admission. So, he begun a semisolid food (soft diet) and we definitively stopped his antidiabetic treatment.

On the 4th day, the patient presented cold sweats followed by loss of consciousness. The diagnosis of hypoglycaemic coma was immediately withheld, with a capillary blood glucose level of $0.36 \mathrm{~g} / \mathrm{L}$.

An infusion of hypertonic glucose serum $10 \%$ instantly normalized its state of consciousness.

After 3 days, a fasting capillary blood glucose checking revealed hypoglycaemia at $0.42 \mathrm{~g} / \mathrm{L}$, confirmed by the plasma glucose measurement. Thus, a discontinuous infusion of GHS 10\% was systematically introduced. Despite this, episodes of hypoglycaemia were still observed. Figure 1 shows the kinetics of fasting capillary glycaemia over time during routine infusion of $10 \%$ GHS.

The other blood tests showed a good renal function with a creatinine clearance: $110 \mathrm{~mL} / \mathrm{min} / 1.73 \mathrm{~m}^{2}$ by MDRD formula (Reference value: $120 \mathrm{~mL} / \mathrm{min} / 1.73$ $\mathrm{m}^{2}+/-20 \mathrm{~mL} / \mathrm{min} / 1.73 \mathrm{~m}^{2}$ ); a good hepatic function with AST $30 \mathrm{IU} / \mathrm{L}$ (Reference value: 7 - 40 IU/L), ALT 25IU/L (Reference value: 5 - 35 IU/L), GGT 40 IU/L (Reference value: 15 - $55 \mathrm{IU} / \mathrm{L}$ ), and total bilirubin $8 \mu \mathrm{mol} / \mathrm{L}$ (Reference value: 3 $22 \mu \mathrm{mol} / \mathrm{L}$ ); a microcytic anemia at $9 \mathrm{~g} / \mathrm{dL}$ (Reference value of hemoglobin: 14 $18 \mathrm{~g} / \mathrm{dL}$ ) after transfusion of 3 blood bags and a glycated hemoglobin at $6.2 \%$ (Reference value: $\leq 7 \%$ ). Dosages of insulinemia and peptide $\mathrm{C}$ were not achieved because of their unavailability.

Regarding the extension assessment, an abdominal ultrasound showed hepatic nodules suspected of malignancy. The chest X-ray showed no metastases. So, it was therefore stage IV gastric adenocarcinoma. Thus, palliative chemotherapy has been indicated. After the announcement of the diagnosis and prognosis, the patient refused the proposed treatment. We then opted for a best supportive care. At the end of hospitalization, the patient had again presented signs of hypoglycaemia, motivating an outpatient infusion of glucose serums.

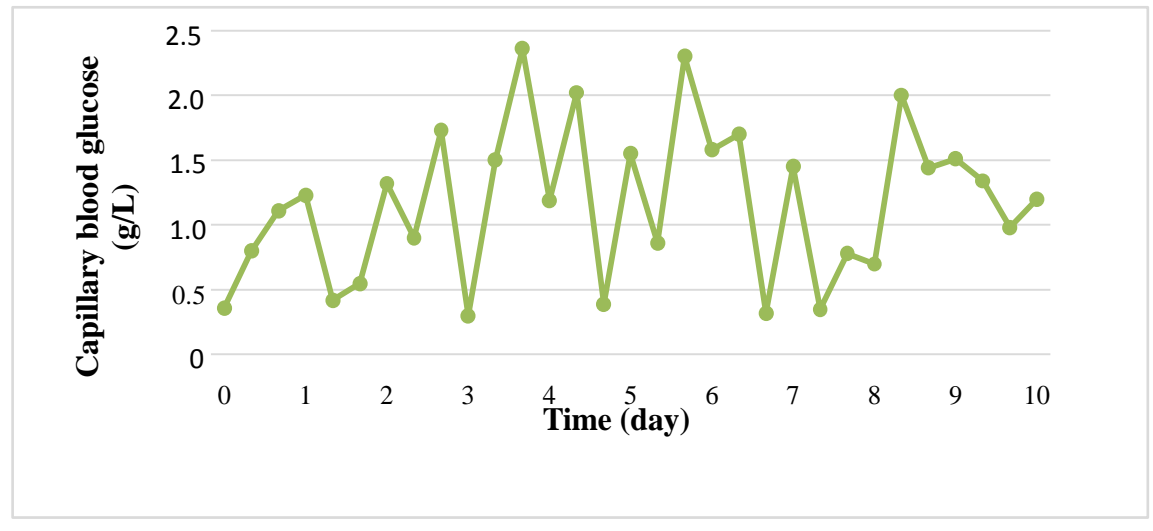

Figure 1. Kinetics of fasting capillary glycaemia over time during routine infusion of $10 \%$ GHS. 


\section{Discussion}

Numerous studies have been conducted on hypoglycaemia in Madagascar, both in Antananarivo and Toliara. But they are mostly focused on hypoglycaemia caused by alcohol [12] [13], leaving aside paraneoplastic hypoglycaemia. Alcohol is known to induce immediate hypoglycaemia [14]. Despite the history of chronic alcoholism in our patient, hypoglycaemia of ethyl origin has been ruled out since alcohol has already been weaned since several years.

Paraneoplastic hypoglycaemia is a rare condition. It is linked to a pancreatic or extrapancreatic tumor. Mesenchymal and hepatic tumours are the most frequently reported in the literature [15] [16] [17]. Those of the digestive tract remain rare [18] [19] [20]. However, the stomach is the most common location in the gastrointestinal tract in $67 \%$ of cases [10] [19] [21]. Like our case, a gastric carcinoma is discovered after a digestive bleeding and hypoglycaemia.

Regarding the circumstances of discovery, to our knowledge there are few studies on the correlation between digestive bleeding and cancer of the digestive tract in Madagascar. A study carried out in the reference center of the Joseph Raseta Befelatànana University Hospital shows that gastric cancer represents only $2.73 \%$ of the causes of upper gastrointestinal bleeding. These are mainly related to duodenal ulcer, which accounts for $31.50 \%$ of cases [22]. Some atypical cases of digestive cancers have also been reported [23] [24]. Gastric adenocarcinoma frequently affects men, aged 60 and over, smoking and having a history of Helicobacter pylori infection. Digestive haemorrhage is manifested in the majority of cases in the advanced stage of the disease [25]. Our patient with melena was diagnosed with metastatic gastric adenocarcinoma. So, we should explore every digestive bleeding to seeking a cancer cause like a gastric cancer.

The hypoglycaemia is the most common acute complication of diabetes. It is most often of iatrogenic origin [26]. The sulfamids are the most incriminated. In fact, the risk of hypoglycaemia due to their use is related to their plasma half-life and their binding to their receptors. For glibenclamide, still widely used in Africa but less and less in developed countries [27], its half-life is 4 to 11 hours and its binding to its receptors is strong and durable, explaining the frequent occurrence of hypoglycaemia. The hypoglycaemia is more frequent and severe in the elderly and/or with renal insufficiency [28]. Our patient took glibenclamide but already stopped for several months before his hospitalization. So, the cause of his hypoglycaemia has no relation with the drug intake. A study carried out on diabetic patients admitted for severe hypoglycaemia in the Joseph Raseta Befelatànana University Hospital shows that $21.33 \%$ of the patients had hypoglycaemia due to renal failure, $13.33 \%$ due to fasting and $10.67 \%$ due to taking antidiabetic drugs. But for $26.67 \%$ of cases, the causes were not specified [29]. Tumour causes including extrapancreatic could have been found, contributing to better management of hypoglycaemia. Further research into the exact cause of hypoglycaemia is necessary to avoid missing the diagnosis of a serious pathology. In the context of cancer, the hypoglycaemia should be suggestive of a paraneoplastic origin. 
Indeed, the clinical manifestations of hypoglycaemia are of two types: neuroglycopenic and neurovegetative. The signs of neuroglycopenia correspond to a deficiency of glucose of the central nervous system and appear for a threshold of blood glucose lower than $0.50 \mathrm{~g} / \mathrm{l}$. They can result in confusion, behavioral problems, drowsiness, visual disturbances, transient motor deficiency, seizure and loss of consciousness. On the other hand, neurovegetative symptoms are related to stimulation of the autonomic nervous system by central hypothalamic activation, which is itself caused by hypoglycaemia, as soon as blood glucose falls below $0.55 \mathrm{~g} / \mathrm{l}$. Sweating, cravings and paresthesia are cholinergic signs, whereas anxiety, palpitation and tremor correspond to adrenergic manifestations [1] [21] [30].

The presence of hypoglycaemia with collapse of insulinemia, peptide $C$ and IGF-1, associated with an increase in IGF-2: IGF-1 ratio, leads to extrapancreatic tumour origin [9] [10] [21]. While an elevation of insulinemia, C-peptide leads to insulinoma [31]. In our case, these biological assessments were not available in our city. Blood samples must be taken to the capital for on-site examination or sent abroad. So the cost remains exorbitant for the majority of Malagasy people, who have no social cover or income sufficient to perform this kind of biological exam knowing that the average income of the Malagasy population is 348 USD per inhabitant per year according to a survey carried out in 2007 [32]. Thus, in our case, the diagnosis was directed to a paraneoplastic syndrome in view of the recurrent characteristics of hypoglycaemia in the absence of favourable factors, in particular the stopping of the oral antidiabetic, and the discovery of a gastric cancer.

Corticosteroid therapy, such as prednisolone at $2 \mathrm{mg} / \mathrm{kg} /$ day, is the basic treatment for paraneoplastic hypoglycaemia associated with tumour-specific therapy [7] [21]. In our case, the patient presented a recurrent hypoglycaemia because he refused chemotherapy and the corticotherapy was not conceivable because he had a gastrointestinal haemorrhage although this one is stopped after a well conducted treatment.

\section{Conclusion}

In the context of cancers in diabetic patients, a paraneoplastic syndrome must be evoked in front of recurrent hypoglycaemia. It is still difficult to confirm in our country, given the lack of adequate technical platforms. A multidisciplinary collaboration between oncologists, endocrinologists and resuscitators would better support this entity.

\section{Conflicts of Interests}

The authors declare no conflicts of interest regarding the publication of this paper.

\section{References}

[1] Cazabat, L. and Chanson, P. (2009) Hypoglycémie et insulinome. Annales D’endo- 
crinologie, 70, S2-S11. https://doi.org/10.1016/S0003-4266(09)72470-9

[2] Germain, C., Perrot, J.L., Labeille, B., Maitre, S., Gentil-Perret, A. and Cambazard, F. (2005) Uncarcinome hypoglycémiant. Annales de Dermatologie et de Vénéréologie, 132, S150. https://doi.org/10.1016/S0151-9638(05)79860-4

[3] Loric, S., Al-Salameh, A., Jeanne, S., Bouras, A. and Coppin, M. (2015) Tumeur fibreuse solitaire évolutive, une cause rare d'hypoglycémies sévères à répétition. À propos d'un cas. Annales d' Endocrinologie, 76, 515-516. https://doi.org/10.1016/j.ando.2015.07.724

[4] Bichali Alroumani, M., Fournier, A.-L., Lerat, F., Defrance, C., Ansquer, C., Mosnier, J.-F., et al. (2016) Hypoglycémies organiques dues à une sécrétion paranéoplasique de pro-IGF2 par une tumeur fibreuse solitaire maligne méningée multimétastatique. Annales d Endocrinologie, 77, 491-492.

https://doi.org/10.1016/j.ando.2016.07.722

[5] Kahn, C.R. (1980) The Riddle of Tumor Hypoglycaemia Revisited. The Journal of Clinical Endocrinology and Metabolism, 9, 335-360.

https://doi.org/10.1016/S0300-595X(80)80037-5

[6] Daughaday, W.H., Emanuele, M.A., Brooks, M.H., Barbato, A.L., Kapadia, M. and Rotwein, P. (1988) Insulin-Like Growth Factor II Synthesis and Secretion by a Leiomyosarcoma with Associated Hypoglycaemia. The New England Journal of Medicine, 319, 1434-1440. https://doi.org/10.1056/NEJM198812013192202

[7] Wémeau, J.-L. (2014) Chapitre 12: Syndromes de sécrétions hormonales paranéoplasiques. In: Wémeau, J.-L., Ed., Endocrinologie, Diabète, Métabolisme et Nutrition pour le Praticien, Springer, Berlin, 197-201. http://www.sciencedirect.com/science/article/pii/B978229471584600012X

[8] Slama, G. (2011) Hypoglycémies réactionnelles ou fonctionnelles: Reactive or functional hypoglycaemias. Médecine Mal Métaboliques, 5, 371-376. https://doi.org/10.1016/S1957-2557(11)70268-1

[9] Jannin, A., Espiard, S., Benomar, K., Cao, C.D., Mycinski, B., et al. (2019) Non-IsletCell Tumour Hypoglycaemia (NICTH): About a Series of 6 Cases. Annales d Endocrinologie, 80, 21-25. https://doi.org/10.1016/j.ando.2018.01.005

[10] Maillot, F., de Widerspach-Thor, A., Lavigne, C., Morbois, L., Renard, J.P. and Couet, C. (2001) Hypoglycémie paranéoplasique par sécrétion de Big IGF-2. Annales d Endocrinologie, 22, S510. https://doi.org/10.1016/S0248-8663(01)80188-0

[11] Azgaou, I., El mghari, G. and El Ansari, N. (2014) P178 Hypoglycémie sévère révélant une tumeur neuroendocrine de localisation grêlique: A propos d'un cas. Diabetes and Metabolism, 40, A70-A71. https://doi.org/10.1016/S1262-3636(14)72469-3

[12] Rakotoniaina, M.M. (2001) Epidémiologie et prise en charge de l'intoxication éthylique aiguë à Tuléar de 1990-2000. Thèse de Médecine, Faculté de Médecine, Antananarivo, No. 5713.

[13] Raveloson, N.E., et al. (2009) Coma alcoolique à Antananarivo: Aspects épidémiocliniques et facteurs de gravité. Revue d Anesthésie-Réanimation et de Médecine d'Urgence, 1, 18.

[14] Auzépy, Ph., Rimailho, A., Mamy, P. and Riou, B. (1983) Le coma hypoglycémique provoqué par absorption d'alcool éthylique. Rev Alcool., 29, 1-12.

[15] Dynkevich, Y., Rother, K.I., Whitford, I., Qureshi, S., Galiveeti, S., Szulc, A.L., et al. (2013) Tumors, IGF-2 and Hypoglycaemia: Insights from the Clinic, the Laboratory and the Historical Archive. Endocrine Reviews, 34, 798-826. 
https://doi.org/10.1210/er.2012-1033

[16] Jha, V.K. and Borpujari, P.J. (2012) Hypoglycaemia Presenting as Sole Manifestation of Hepatocellular Carcinoma. Medical Journal Armed Forces India, 68, 75-77. https://doi.org/10.1016/S0377-1237(11)60113-5

[17] Wong, A., Somarajah, G., Deb, S., Cheung, A.S., Davis, I.D., Cebon, J., et al. (2010) Non-Islet Cell Tumour Hypoglycaemia Due to Clear Cell Hepatocellular Carcinoma. Pathology, 42, S76. https://doi.org/10.1097/01268031-201042001-00169

[18] Affes, L., Ben Nasr, B., Rekik, N., Chaâbane, A., Charfi, N. and Abid, M. (2014) Hypoglycémie paranéoplasique: A propos d'un cas. Annales d'Endocrinologie, 75, 367. https://doi.org/10.1016/j.ando.2014.07.324

[19] Montgomery, J.A. and Berne, C.J. (1974) Gastrointestinal Tract Neoplasms with Dependent Hypoglycaemia. The American Journal of Surgery, 127, 737-739. https://doi.org/10.1016/0002-9610(74)90360-2

[20] Ben Said, R., Ftouhi, B., Bousselmi, J., Ben Nacef, I., Chihaoui, M. and Slimene, H. (2013) Tumeur stromale de l'intestin grêle révélée par des hypoglycémies sévères. Annales d Endocrinologie, 74, 378-379. https://doi.org/10.1016/j.ando.2013.07.488

[21] Morbois-Trabut, L., Maillot, F., De Widerspach-Thor, A., Lamisse, F. and Couet, C. (2004) "Big IGF-II"-Induced Hypoglycaemia Secondary to Gastric Adenocarcinoma. Diabetes \& Metabolism, 30, 276-278. https://doi.org/10.1016/S1262-3636(07)70119-2

[22] Razafimahefa, S.H., et al. (2011) Hémorragies digestives hautes: Aspects cliniques, endoscopiques et évolutifs. A propos d'une série de 62 patients malgaches. Rev Med Madag, 1, 6-10.

[23] Rakoto Ratsimba, H.N., Rabesalama, S.S.E.N., Rakotoarisoa, A.J.C., et al. (2007) Hémorragie digestive du sujet jeune: Possibilité d'une tumeur stromale. Rev Trop Chir, 1, 31-32.

[24] Rajaonanahary, T.M.A., Rambel, A.H., Rakotovao, M., et al. (2009) Un cas de léiomyome gastrique de découverte fortuite. Rev Trop Chir, 3, 61-62.

[25] Sweed, M.R., Edmonson, D. and Cohen, S.J. (2009) Tumors of the Esophagus, Gastroesophageal Junction, and Stomach. Seminars in Oncology Nursing, 25, 61-75. https://doi.org/10.1016/j.soncn.2008.10.005

[26] Lubetzki, J., Chanson, P. and Guillausseau, P.J. (2005) Endocrinologie et maladies métaboliques. Flammarion, Paris.

[27] Stahl, M. and Berger, W. (1999) Higher Incidence of Severe Hypoglycaemia Leading to Hospitaladmission in Type 2 Diabetic Patients Treated with Longacting versus Short Acting Sulphonylureas. Diabetic Medicine, 16, 586-590. https://doi.org/10.1046/j.1464-5491.1999.00110.x

[28] Blicklé, J.F. (2012) Traitement du diabète en dehors de l'insuline. In: Grimaldi, A., Ed., Traité de Diabétologie, 2è Edition, Flammarion, Paris, 15372.

[29] Raherison, R.E., Raharinavalona, S.A., Ratsimbazafy, S.J.N., Randriamboavonjy, R.L., Rakotomalala, D.P. and Raveloson, N.E. (2015) Profil épidémio-clinique des diabétiques admis pour hypoglycémie sévère à l'Hôpital Joseph Raseta Befelatànana d'Antananarivo. Rev. méd. Madag, 5, 611-615.

[30] Bossu Estour, C., Guillaume, M., Sarrot Reynauld, F., Rouge, P.E., Bouillet, L., Massot, C., et al. (2010) Une histoire de sucre bien salée. La Revue de Médecine Interne, 31, 243-246. https://doi.org/10.1016/j.revmed.2009.11.004

[31] Baudin, É., Caron, P., Lombard-Bohas, C., Tabarin, A., Mitry, E., Reznick, Y., et al. (2014) Recommandations pour la prise en charge de l'insulinome malin. Presse 
Médicale, 43, 645-659. https://doi.org/10.1016/j.lpm.2013.08.007

[32] Institut National de la Statistique (INSTAT) et ICF Macro (2010) Enquête Démographique et de Santé de Madagascar 2008-2009. INSTAT et ICF Macro, Antananarivo. 